Towards the Permissive Society? Morality Policy Agendas and Policy Directions in Western Democracies*

Donley T. Studlar

School of Government and Public Policy

University of Strathclyde

McCance Building, 16 Richmond Street

Glasgow $\mathrm{G} 1 \mathrm{HQ}$

Scotland, United Kingdom

and

Gordon J. Burns

Dept. of Political Science, West Virginia University

P.O. Box 6317

Morgantown, WV 26506-6317 USA

Contact author: donley.studlar@strath.ac.uk

OLIC-D-14-00062R3

(forthcoming in Policy Sciences, Vol. 48, 2015)

*Paper presented at European Political Science Association Edinburgh, Scotland, June 19-21, 2014 and to staff seminar at the University of Strathclyde, March 2014.

Thanks to commentators at these sessions, especially Anthony McGann of Strathclyde, and to William Harrison and Alessandro Cagossi, then graduate students at West Virginia University, for their assistance in data gathering and translation. 
Toward the Permissive Society? Morality Policy Agendas and Policy Directions in Western Democracies

Introduction

Although various issues have been labeled as part of "morality policy," their presence, persistence, and degree of controversy varies across countries (Studlar 2001; Smith and Tatalovich 2003; Engeli et al. 2012a; Knill 2013). Some issues such as alcohol temperance and prohibition that were major, ongoing political controversies in several Western democracies a century ago have now subsided largely into more routine regulatory policy, sometimes at a different level of government, with only occasional outbreaks of debate at the central level (Frendreis and Tatalovich 2010; Donovan et al. 2015). But other morality issues have persisted for greater or lesser amounts of time, including capital punishment (death penalty), abortion, same sex domestic relationships (gay marriage), assisted reproductive technology/stem cell research (ART), and euthanasia (assisted suicide). All five of these policies are concerned with birth, sex, and/or death. These kinds of intimate relations are particularly susceptible to becoming politicized as morality issues. Even if the issues are complex and susceptible to scientific and economic influences, they deal with fundamental human concerns that many people in a society consider to be easily understood and on which they can become politically mobilized. This is especially true for groups concerned with religious or human rights principles; advocates from these groups wish to have their governments adopt policies in line with their often strongly value-based views, even if this conflicts with others in society. 
There has been increasing recognition that morality policy in Western democracies is a distinctive field of study, but many analyses of morality policy are relatively narrow, often being based on one issue and/or a small number of jurisdictions (Mooney, 2001; Kollman 2013; Stetson 2001). Even more theoretically ambitious comparative studies may be based on only a few jurisdictions and issues (Smith and Tatalovich 2003; Engeli et al. 2012a; Schmitt et al. 2013). In contrast, we use a large and unique data set to present the most broadly comparative empirical study of morality policy agendas, specifically current content and duration of debate, across Western liberal democracies, including multiple issues and developments over an extended time period.

Based on a large comparative data set, this paper examines the patterns of policy agenda-setting—content and duration--for five morality policy issues across 24 advanced industrial democracies in Europe, North America, and the Asia-Pacific region since World War II. The issues are two long-standing morality issues, capital punishment and abortion, and three of more recent vintage: euthanasia, assisted reproductive technology/stem cell research, and same sex domestic relations.

What is the overall direction of the policy adoptions? What is the duration of these issues on the policy agenda? We analyze these questions through a broad overview of policy developments since 1945. To varying degrees, these issues have been on the agendas of all of these countries, but there is a lack of systematic comparison of their status. One might expect that the general process of secularization, modernization, and individualism occurring across Western democracies has moved all of them toward more permissive policies on issues on which previously entrenched 
religious and cultural practices influenced governments toward restrictive policies (Norris and Inglehart 2011). Nevertheless, the process may vary across countries by institutions as well. How uniformly have Western democracies moved from restrictiveness toward permissiveness in the post-1945 period? How long have these issues been debated?

This paper will consider 24 Western democracies In addition to presenting data on the patterns of content and duration for five major morality policies in these countries, we shall also examine the applicability of two common explanations of morality policy across countries: 1) Policy Types and 2) the 'Two Worlds' of religious and secular party systems. We shall also examine whether there are differences in major subsets of Western democracies, specifically Western Europe (the largest number, 18), non-European democracies (6), and the U.S. as an exceptional case. We seek to describe and explain the larger patterns in our data, leaving detailed examination of individual policies, institutions, and countries for future research.

\section{Literature Review and Theory}

Most public policy texts, especially those published outside the United States, do not have a separate index entry for, much less any discussion of, what has come to be called "morality policy" (cf. Knill and Tosun 2012: 18-19) ${ }^{1}$. Nevertheless, increasingly analysts have contended that some issues have such significant similarities in the content, framing, and/or processes by which they are decided that they deserve to be considered as a common category (Mooney 2001; Smith and Tatalovich 2003; Roh and Berry 2008; Schwartz and Tatalovich 2009; Engeli et al. 2012a; Knill 2013; Ryan 2014). 
Much of this literature is written by U.S. political scientists about U.S. politics, raising questions about its general applicability. Most morality policy studies outside the U.S. also focus on individual countries, such as the United Kingdom, Denmark, and Canada, and, more recently, Austria (Christoph 1962; Richards, 1970; Marsh and Read 1988; Cowley 2001; Durham 2005; Skjæveland 2001; Albæk 2003; Rayside and Wilcox 2011; Knill et al. 2014).

There has been considerable debate about whether morality policy exists as a discernible category of policy, and if so, how to identify it (Smith 1969; 1975; Tatalovich and Daynes 2011; Wald et al. 2001; Mooney and Schuldt 2008; Roh and Berry 2008; Studlar 2008; Mucciaroni 2011; Knill 2013; Ryan 2014). The prevalent tendency in previous research, especially in the U.S. (Donovan et al. 2015), is to argue that morality policy is defined by process as well as by content. Comparative research across countries on morality issues, however, has been more conflicted over whether cultural, institutional, group, diffusion, or partisan factors are more important influences on policy outcomes (Field 1979; Halfmann 2011; Varone et al. 2006; Cohan 1986; Lijphart 2012; Green-Pedersen 2007; Montpetit et al. 2005; 2007; Banchoff, 2011; Albaek 2003; Grießler and Hadolt 2006; Smith and Tatalovich 2003; Engeli et al. 2012a; Neumayer 2008; McGann and Sandholtz 2012; Kollman 2013).

Furthermore, even if it varies somewhat from one country to another, policy content, especially over the short-to-medium term, is an important defining dimension of morality policies (Studlar 2001; Smith and Tatalovich 2003; Engeli et al. 2012a). As Mooney (2001) indicates, it takes only one side to consider an issue as being one of morality in order for these dimensions to be presented as part of the debate, but 
sometimes both sides consider an issue to be morally based, one of clashing rights between two groups, or between individuals and group sentiment. This is not to deny that other issues may have moral dimensions and potentially life-threatening repercussions, but the five examined here are well documented as involving morality conflict in several countries.

Most U.S. studies generally have adopted a version of Lowi's (1964) policy typology to explain the findings, especially in regard to processes (Smith 1969; 1976; Tatalovich and Daynes 2011; Mooney 2000). Different types of policies involve different institutional processes, even in the same political system, and a category of 'morality policy' (variously called emotive symbolic politics or social regulatory policy) is a bottom-up process involving large-scale public and interest group involvement, divisive party and legislative politics, and abdication of executive leadership on the central level. While this approach has little to say about policy outcomes, some of its exponents have argued that permissive or restrictive content is dependent on either elite opinion overcoming mass resistance (Smith and Tatalovich 2003) or the capacity of U.S. federalism to allow different parts of the country to adopt different policies, depending on mass preferences in those jurisdictions (Mooney 2000; Donovan et al. 2015). ${ }^{2}$

But U.S. political institutions significantly differ from those of most other advanced industrial democracies. In the U.S., federal system, many "morality policies" arise from the "policy shocks" of judicial decisions based on individual cases that generate a reaction among the public and other institutions and eventually are resolved at the state and local level (Mooney 2000; Donovan et al. 2015). Also, the U.S. is considered particularly susceptible to issues with strong moral arguments; its residents 
are more willing to argue on the basis of "individual human rights" as well as to profess and practice religious faith, leading to moralistic political cleavages that become part of partisan debate (Tatalovich 1997; Schwartz and Tatalovich 2009; Studlar 2012).

More recently, some scholars have examined comparative morality policy in Europe, through a Two Worlds theory focussed on the nature of party conflicts around these issues. This explanation covers levels of political attention, which parties are driving the conflict, and whether the composition of the government matters. The most important variable is the nature of the party system, especially whether a major "confessional" party with close ties to a (usually Roman Catholic) church influences the agenda and resolution of morality policy disputes (van Kersbergen 2008; Fink 2008; 2009; Engeli et al 2012a). In post-war Europe, more secular parties raise these issues to put religiously-based parties on the defensive, making them take more diffuse, 'unsecular' stands based on general social principles, such as family protection, rather than religion per se. Debates over morality issues are more party-focussed in these "religious party system" countries than in those with a secular party system in which no significant party has a strong religious organizational tie.

While the Two Worlds model provides an alternative approach, it is not necessarily mutually exclusive to the Policy Type theory. The Two Worlds theory recognizes that morality policy is a prima facie distinctive category of issues and examines how political conflicts are structured within the existing institutions of a country. Insofar as these institutions vary, such as the ease of referendums in Switzerland, then the locus of the conflict may differ. It also accepts that the attempt to 
change morality policies may lead to divisions within parties in the legislature, especially in secular party systems.

The proponents of the Two Words theory have relatively little to say about policy content (Heichel et al. 2013). Nevertheless, even though there is a focus of resistance to permissiveness in the church-party nexus in a religious party system, paradoxically, these countries may adopt more permissive policies earlier once secular parties promoting such policies gain sufficient control of the government, in contrast to the more diffuse, party-splitting morality advocates in secular party systems (Engeli et al. 2012b;

2013). ${ }^{3}$ But Schmitt et. al (2013) and Engeli and Rothmayr (2013), for different issues, demonstrate that this process is contingent across party systems. ${ }^{4}$

Morality policy as process has been analyzed in recent papers building on both the U.S. and comparative European literature (Studlar et al. 2013; Studlar and Burns 2014). This paper focuses on understanding comparatively the agenda of morality policy in Western democracies, including duration of debate on these issues as well as the policy outputs as of December 2014. It follows Freeman (1986) in examining both policies and countries to see what variables are influential comparatively on policy adoption. Thus we examine 24 Western democracies as well as aggregate data for five morality policies in order to ascertain the patterns.

\section{Hypotheses}

The variables and expectations for policy process theory are derived from previous studies of morality policy as a distinctive policy type. These studies agree that morality policy is not subject to "ordinary" executive-led party government and cohesive party votes. Instead, it features different institutional processes: legislative party 
initiatives, divided party votes, judicial decisions, constitutional actions, decentralized consideration, and referendums, plus the total number of venues involved in each country (Smith 1969; 1975; Cohan 1986; Tatalovich and Daynes 2011; Outshoorn 1996; Studlar 2001). The availability of these institutions may have varying effects on different dimensions of morality policies, such as content and duration, depending on the relative strengths of forces for change and resistance in the countries. The availability of a particular venue, or the number of them, may offer different opportunities for either side; the willingness and capacity of the groups to exploit these opportunities, however, may differ. $^{5}$

For instance, the existence of decentralization may allow a pro-change group to pursue its goal in several different parts of a country, but it also allows resistant forces to do the same. One may be more successful than the other, as for instance has occurred in the U.S. in regard to abortion restrictions in state legislatures in recent years. Any directions will be shown in the tests of these hypotheses.

Thus we offer the following hypotheses from the Policy Type model, based on previous literature about how contending groups try to use institutions to push and resist change. Brief reasoning is provided for each hypothesis.

a) The more venues involved in a country, the less permissive the content and the longer the duration. ${ }^{6}$ Reasoning: More venues provide the opportunity for delays in the processing of issues and compromises in content.

b) In countries where this venue is available, the more decentralization is used, the less permissive the overall policy and the longer the duration. Reasoning: 
Decentralization leads to delays and difficulties in generating a uniform policy across the country.

c) In countries where it is available, the more referendums, the less permissive the policy and the greater the duration. Reasoning: The mass public is generally conservative on morality issues; referendums provide an opportunity for either side to extend the debate beyond the usual political institutions.

d) The more party divisions, the less permissive the policy and the greater the duration. ${ }^{7}$ Reasoning: Party divisions make it more difficult to pass changes in policy.

e) The more legislative initiatives, the more permissive the policy and the greater the duration. Reasoning: Legislative initiatives are available to challenge existing restrictive policies; however, unless there is support from the executive, debate is likely to be prolonged.

f) The more judicial involvement, the more permissive the policy and the shorter the duration. Reasoning: Judiciaries can act to resolve disputes in policy, often abruptly.

g) The more constitutional involvement, the more permissive the policy and the longer the duration. Reasoning: Constitutional references can resolve policy disputes through amendment or interpretation, but they usually take time.

Similarly, we test two hypotheses about the nature of the party system upon 
content and duration of morality policies.

h) In the long run, religious party systems have more permissive general morality policies. Reasoning: Despite religious party resistance, eventually secular parties gain power, enabling them to change policies.

i) Religious party systems have longer duration of morality issues. Reasoning: Having a significant religiously-oriented party makes it more difficult to pass more permissive legislation.

Finally, we examine whether there are differences between Europe, other nonEuropean democracies, and the U.S. on morality policy agendas. The expectation is that content will be more permissive and duration shorter in Europe, with non-European democracies in the middle, and the U.S. being most restrictive in content and longest in duration. Reasoning: The U.S. has multiple venues and a large proportion of religious supporters mobilized into political support, both of which lead to long conflicts over value changes and uneven outcomes. European countries are smaller, more centralized, and more secular in values, which can overcome religious party resistance to policy change. Non-European democracies exhibit some features of both of these systems.

Concepts, Data, and Methods

As indicated previously, the major research questions are to determine the patterns of distribution of these issues comparatively across space (countries) and time, based on available data, and offer a preliminary assessment of what might help explain variations in morality policy agendas and outcomes. By 'agenda', we mean the morality 
issues that are part of the countrywide political discussion in a particular year and over time, based on documentary and secondary sources. Following Heichel et al. (2013), 'content' (or direction) refers to the nature of the policy at the beginning of 2014, based on the judgment of the authors:- restrictive, intermediate, or permissive-scored as 0 , 5 , and 10 respectively. In order to produce a consistent scale of restrictivenesspermissiveness (or 'conservatism-progressivism'), we reverse the scoring for capital punishment to make its abolition coincide with the 'permissive' or 'progressive' end of the continuum. ${ }^{8}$ Countries lacking a codified policy usually are considered to be "permissive" since there are no formal limitations, but in some cases, overwhelmingly dominant social norms and practices, as on euthanasia in Germany and Greece, indicate that other content designations are appropriate.

"Duration" refers to the beginning and ending dates for the issue on the policy agenda of any governmental institution (not only the executive). The end of World War II in 1945 is the earliest possible start time since research beyond that becomes difficult. Significant events include official government reports, proposed legislation and debate, enactments, judicial decisions, and referendums. Duration of the policy is from its first official agenda status until the last recorded official policy consideration, usually the latest adoption of legislation but also including further institutional consideration where relevant.

Not all countries have all of these institutional venues for policy debate. Of the six venues presented, all 24 of the countries, in principle, have four (legislative initiatives, party divisions, judicial involvement, and constitutional conflict). Referendums on policy issues are readily available in only ten (Australia, Canada, Denmark, Ireland, Italy, 
Japan, Luxembourg, New Zealand, Portugal and Switzerland) although the actual number of referendums conducted varies substantially across these countries (Gallagher et al. 2011). While it is not clear which countries could, in principle, allow morality issues specifically to be decentralized, we identify twelve countries as having significant general decentralization of institutions (Australia, Austria, Belgium, Canada, Denmark, Germany, Italy, Netherlands, Spain, Switzerland, the United Kingdom, and the United States) (Hooghe et al. 2010; Lijphart 2012).

For party systems, we follow the designation of 'religious' and 'secular' systems based on the importance of a major party with strong religious ties, usually Christian Democratic. $^{9}$ There are ten consistently religious party systems: Austria, Belgium, Germany, Israel, Luxembourg, Netherlands, Portugal, Spain, Switzerland, and the United States. The following 14 countries consistently have secular party systems: Australia, Canada, Denmark, Finland, France, Greece, Iceland, Ireland, Japan, New Zealand, Norway, Sweden, and United Kingdom. As the nature of the party system in Italy has been the subject of continuing debate among scholars (Engeli et al. 2012a; Cagossi 2013), we calculate religious/secular party system differences in two ways to account for this system's indeterminate standing.

We shall consider both patterns across countries as well as by issues in terms of content and duration of policies. ${ }^{10}$ Data were gathered from multiple sources, 19452014 , on the five policies to be examined here--the death penalty, abortion, euthanasia, same sex marriage, and ART/stem cells (Albaek 2003; Blank and Merrick 2001; Bleiklie et al. 2004; Burrell 2006; Cohen and Jones, 2004; Council of Europe 1999; Badinter et al. 2004; Cowley 2001; Engeli 2009; Engeli et al. 2012a; Hood and Hoyle 2008; 
International Planned Parenthood Federation European Network 2009; Ketting and van Praag 1986; Kollman 2013; Klinh and Trappenburg 2001; Marsh and Read 1988; Montpetit et al. 2005; 2007; Outshoorn 1996; Richards 1970; Engeli and Rothmayr Allison 2013; Rolston and Eggert 1994; Singh et al; 2009; Stetson 2001; Walsh et al. 2011; Engeli et al. 2012b; Itaborahy and Zhou 2013; Isasi and Knoppers 2006; Gottweis et al. 2009; "Stem Cell World Map"). In the data analysis for the hypotheses, bivariate regression analysis, t-tests, one- way ANOVA, and the nonparametric MannWhitney $U$ test are employed as needed. ${ }^{11}$

\section{General Findings: Policy Content}

(Tables 1 and 2 about here.)

Table 1 presents the scores for content and duration of morality policy overall and by country. Table 2 shows the summary data by issues. Based on the ten--point scale of restrictiveness-permissiveness and summarized across all five issues (Table 1 ), the mean is 6.7 , between intermediate and permissive, but there is considerable variation. Perhaps surprisingly, the most progressive countries are not the Nordic ones, but Belgium (10), followed by Netherlands, Sweden and the United Kingdom (9), Canada, Luxemburg, and France (8) to Austria, Finland, Greece, Ireland, Israel, Japan, and the USA (5) and finally Italy (3) although only the latter would qualify as 'restrictive'. While the USA is one of the countries rated as 'intermediate', it is not as distinctive in that regard as some might expect from its reputation in some quarters as a redoubt of conservatism.

The scores for each of the five individual issues across all countries (Table 2) reveal that, in content, euthanasia remains the most restrictive policy (3.4), followed by 
ART/stem cells (6.0), same sex marriage (6.9), and abortion (7.9), and capital punishment (9.4). While the overall scores for Europe and non-Europe are very similar, Europe is less conservative on capital punishment, abortion, and same sex marriage but more conservative on ART; the scores for euthanasia are identical. Probably this is because of a combination of the influence of Catholicism as well as suspicions, even on the left, about the benefits of science (Bleikle et al 2004; Montpetit et al. 2007). On euthanasia and same-sex domestic relationships the two groups of countries are essentially identical. Western, especially West European, democracies are hardly the overall bastions of permissiveness that some observers claim. Nevertheless, there is a strong post-war tendency toward that end although varying considerably by issue.

As indicated in Table 1, although capital punishment sometimes took extended courses, today this is largely a settled issue. All except three countries are restrictive, having banned capital punishment, some even inserting this prohibition into their constitutions. Increasingly there has been pressure from European international organizations, such as the Council of Europe and the European Union, to adopt such a restrictive policy. There is a pan-European consensus on this topic; the holdouts are elsewhere, namely the United States, Japan, and Israel, but even these countries have reduced their use of the death penalty, and in the U.S. some states have abolished it completely (McGann and Sandholtz 2012; Mooney and Lee 1999).

Although the contemporary content of abortion policy is not as uniform as in the case of capital punishment, all democracies have either permissive or intermediate laws, allowing it under specific circumstances (Ketting and Prang 1986; Outshoorn 1996). Thus, as with capital punishment, abortion has been a long-term contentious 
issue with a definite policy convergence toward one end of the continuum.

Euthanasia has been more selectively discussed, with reform proposals more numerous than policy changes. Belgium, Luxembourg, and the Netherlands have joined the long-time leader, Switzerland, as the most permissive on this issue. While some other countries have adopted intermediate policies, overall this issue is the one on which extant policies are still the most conservative.

ART debate has resulted in a variety of outcomes, resulting in the second lowest overall mean score. While almost all countries have been willing to address the issue, there is not a strong convergence of policy outcomes. Furthermore, it has been found that there is no strong association between policy content on this 'red technology" issue and the "green technology" of genetically-modified organisms (GMOs) for food production (Varone and Schiffino 2004; Montpetit et al. 2007). One might expect that as a relatively new issue with scientific as well as morality dimensions, ART would be particularly susceptible to policy changes. But in most countries debate has subsided in the past decade after an initial period of controversy and policy differentiation (Bleikle etal. 2004; Montpetit et al. 2007; Isasi and Knoppers 2006; Engeli and Rothmayr Allison 2013).

Same sex marriage has been the issue that has moved relatively rapidly in a uniformly more permissive direction since Denmark became the first Western democracy to allow 'civil unions' in 1989. With the exception of Greece, all other countries here have either permissive or intermediate policies, several of them only recently adopted (Kollman 2013).

Overall, there is a clear trend toward greater permissiveness (liberalization) of 
policy in all of these areas and away from traditional, often Christian-based morality. Yet there remains a considerable amount of moral diversity among Western democracies, even in Europe (see Engeli and Rothmayr Allison 2013). Countries are not always consistent in their policies on related issues or even what one might expect on various measures of scale of religious observance (Minkenberg 2002; Engeli et al. 2012a; Norris and Inglehart 2011). One reason for this may be the relative preferences of professional and activist groups within countries for de facto tolerance of informal practices that may deviate from the law, in contrast to de jure formal government policies. In other words, an attempted change, usually towards liberalization, of morallycharged policies can lead to ongoing political conflict, which some countries prefer to leave in the less formal social realm (Timmermans 2001; Outshoorn 1996; GreenPedersen 2007).

\section{General Findings: Duration}

Table 1 lists the starting and ending dates for post-war political debate on these policies, which vary by issue. However, the initial year for individual issues is similar across countries. Debate ends on Issues in an even narrower range, across 20 years in the 1990s and 2000s, but of course some continue. The mean starting year across all five issues is 1973, but there is considerable variation, ranging from abortion (1955) and capital punishment (1957) to same sex marriage (1997). ${ }^{12}$ The current end point of debate is more limited, with an overall mean of 2001, ranging between the death penalty and abortion resolved in the 1990s in most countries to euthanasia, ART, and same sex marriage debates continuing beyond that. 
The post-World War II mean for duration across all morality issues for all countries is 29 , ranging from 63 in the USA to less than five in Greece. The mean number of years of official debate ranges from the 50 for abortion and capital punishment to 30 for euthanasia, 26 for ART, and 14 for same sex marriage. Across all five issues, there is a close coincidence between European and non-European countries in starting and ending dates as well as duration, suggesting that, whatever the sources, the agenda for morality issues is similar in Western democracies, despite their very different religious and cultural compositions. Nevertheless, there is some variation by individual issues, with euthanasia debates starting earlier and ART later in nonEuropean countries, with consequently longer and shorter durations.

Whatever the variations in duration, each of these five issues has been on the political agendas of practically all Western democracies. Capital punishment and abortion are relatively "old" morality issues in that they have been debated in some jurisdictions since the nineteenth century and even earlier (Rolston and Eggert 1994). These deliberations have been sporadic rather than continuous, both across time and countries, however, until after World War II when questions of human rights and, in the case of abortion, medical technology allowing increased survivability of severely disabled infants became more prominent.

Euthanasia was the third of these morality issues to reach the political agenda more broadly although it is an old issue in a few countries such as Switzerland. With greater human longevity, increasing medical care costs, and more emphasis on individual choice, euthanasia has become a more prevalent issue since the 1990s. 
In most countries consideration of ART began in the 1980s, driven by scientific developments, notably including the first "test-tube baby" in 1978 (Montpetit et al. 2005; 2007; Bleikle et al, 2004; Deech and Smajdor 2007). All of the Nordic countries except Iceland, however, had very early reports on some dimensions of ART (Burrell 2006). These debates, in their various dimensions such as in-vitro fertilization (IVF), surrogate parentage, cloning, age and relationship limitations, and eventually human stem cell research, have proceeded at different times and speeds (Mintrom and Ballard 2009; Isasi and Knoppers 2006; Gottweis and Prainsack 2006).

Policy toward same sex domestic relations is a recently arising human rights issue. Overall public views in Western democracies have changed over the decades following earlier guarantees of basic rights for homosexuals and greater sympathy for the desire of this group for more inclusive forms of participation in society (Itaborahy and Zhou 2013; Kollman 2013).

Findings: Policy Type

(Table 3 about here.)

Expectations from Policy Type theory on the role of institutions in the content and duration of morality policy (see above) were tested through the use of bivariate linear regression and associated statistics. The results are presented in Table 3. Of the total of 14 general bivariate hypotheses tested concerning the effect of political institutions (total venues, decentralization, referendum, party divisions, legislative initiatives, judiciary, and constitution) on the duration and content of morality policies, only three were confirmed. All of these were for significant effects on duration; none were related to content. They were 1) total venues and duration, <.01;2) party divisions and duration, 
$<.01$; and 3) legislative initiatives and duration, $<.01$. These findings suggest that these particular avenues do provide mechanisms for raising and maintaining controversies over morality issues.

Findings: Two Worlds

(Table 4 about here.)

Data for the hypotheses from the Two Worlds model is presented in Table 4, with significance tests conducted utilizing the nonparametric Mann-Whitney U. As noted previously, the number of religious and secular party system countries varies depending on where Italy is placed. Overall, however, we found no significant differences for any of the hypotheses on content and duration, irrespective of whether Italy was considered as a religious or secular party system. In contrast to earlier findings on Western Europe (Studlar et al. 2013), this particular dimension of the Two Worlds model does not find support in the broader cross-national data.

Europe and Other Western Democracies, including USA

(Table 5 about here.)

But are there any patterns applicable for European countries, non-European democracies, and the U.S. in particular? As indicated previously, despite similar institutional processes, we might expect European countries to have more permissiveness and shorter duration of policies, followed by non-European countries in each category, with the U.S. by itself as having the least permissiveness and longest duration. In order to test these, we conducted difference of means tests across the averages for all three groups as well as between the groups. See Table 5 . The only 
tests resulting in statistical significance were those for duration between Europe and the U.S. $(<0.1)$ and non-Europe versus the U.S. $(<.05)$ although all of the directions were as hypothesized. ${ }^{13}$ The U.S. has longer debates than other Western democracies, but not appreciably different policy outputs.

\section{Conclusions}

Thus far we have found only limited applicability for the two most general explanations for morality policy agendas and outcomes. Examining the relationship of 1) Policy Type and 2) the Two Worlds explanations to the content and duration of morality policy across 24 Western democracies in the post-World War II period, we have found no results for the second but some limited confirmation for the first. There is some evidence that what are often considered key institutional dimensions differentiating morality policy from others, namely legislative initiatives and party divisions in legislative votes on such issues, are related to duration of these issues. Similarly, total venues used in morality debates are related to duration. But other Policy Type institutional hypotheses are not supported. No support is found for hypotheses about the differences between religious and secular party systems, even considering alternative versions of the problematic case of Italy. ${ }^{14}$ There are no significant differences between European and non-European countries on these dimensions. U.S. exceptionalism, however, is affirmed in terms of its differences with both of these other groups in duration (greater differences from Europe), but not content.

However, morality policy studies focusing on the explanations of process rather than agendas and content (Studlar et al. 2013; Studlar and Burns 2014) have found some explanatory power for the Two Worlds theory as well as Policy Type. Thus there 
may be some form of interaction of institutions, party systems, and the policy agenda. Furthermore the relationships of specific venues and policies, both those examined here and others, remain to be explored. Some studies of the death penalty (Van Koppen et al. 2002; McGann and Sandholz 2012; Lijphart 2012), have found support for the set of related institutions a (proportional representation, multi-party legislatures, coalition governments) characteristic of consensus democracy as well as presidential vs. parliamentary democracies, but other individual morality issues remain to be examined.

Since World War II, the West has experienced a change in morality policy debate, albeit an uneven one in location, content and duration. As societies have become more secular and more diverse in values, morality policy often has become controversial because it is "socially redistributive". To move from a legal ban on abortion, assisted suicide, or same sex domestic relationships is a dramatic directional change for large numbers of people in a democratic polity, creating distinct winners and losers in values endorsed by the government. Even incremental steps concerning the adoption of different policy instruments or calibrations of instruments may be difficult. At some point, the scale of policy changes on these morality issues may represent a paradigm change (Hall 1993) in legitimating the preferences of one side. Such clashes related to elite and mass values can generate controversy over extended periods.

These issues have been on the agendas of all of the countries and the content of policy has moved toward permissiveness, but there still remains considerable policy diversity, especially on the newer issues of euthanasia, same sex marriage, and ART. All of these issues remain on the active public agenda in some countries. How long this will be the case depends on whether they can be resolved in a stable manner. Within 
the general trend of progressive movements on all of these issues, restrictiveness and even constitutionally-based abolition of the death penalty is pervasive, relatively permissive abortion has become a "stable compromise" in most places, and same-sex marriage has become a trend. There is most variation, from permissive to restrictive, on ART and euthanasia policies although both have undergone overall liberalization over the past 20 years despite persistent resistance. The varying patterns of convergence and divergence on these policies, even among similar political regimes and issues, indicate that the cultural, institutional, and international factors leading to these outcomes still need careful examination.

This first extensive cross-country analysis of morality policy content and duration has limits. It provides an aggregate analysis of the patterns of these five common morality policy issues across Western Europe. Other morality policies may also be considered $^{15}$, case studies can be done on one or more issues in particular countries, and improved metrics for the variables might be developed. ${ }^{16}$ The involvement of the public, both through general attitudes on values as well as mobilization through interest groups, needs to be examined, but this is difficult to do in a comparative study across multiple countries. Diffusion may be an important dimension for at least some of these policies (McGann and Sandholtz 2012: Kollman 2013). There also needs to be more direct comparison with explanations for non-morality policies. Thus there is the prospect of further cumulative work in understanding morality policy theoretically across Western democracies. 


\section{References}

Albæk, E. (2003). Political Ethics and Public Policy: Homosexuals Between Moral Dilemmas and Political Considerations in Danish Parliamentary Debates. Scandinavian Political Studies, 26 (2), 245-267.

Badinter, R., Bedau, H.A., Hodgkinson, P., Hood, R., Ferrazzini, R.A., Forst, M. et al. (2004). Death Penalty: Beyond Abolition. Strasbourg: Council of Europe.

Baumgartner, F.L. \& Jones, B.D. (1993) Agenda-Setting in American Politics Chicago: University of Chicago Press.

Baumgartner, F.R., De Boef S.L. \& Boydstun, A.E. (2008). The Decline of the Death Penalty and the Discovery of Innocence. New York, Cambridge University Press.

Banchoff, T. (2011). Embryo Politics: Ethics and Policy in Atlantic Democracies. Ithaca, NY: Cornell University Press.

Blank, R. H. \& Merrick, J.C. (2001). End-of-Life Decision Making: A CrossNational Study. Cambridge: The MIT Press.

Bleiklie, I., Goggin, M.L. \& Rothmayr, C. (eds) (2004) Comparative Biomedical Policy: Governing Assisted Reproductive Technologies. London: Routledge.

Bryld, M. (2001). The Infertility Clinic and the Birth of the Lesbian: The Political Debate on Assisted Reproduction in Denmark. European Journal of Women's Studies, 8 (3), 299-312.

Burrell, R. (2006). Assisted Reproduction in the Nordic Countries: A Comparative Study of Policies and Regulation, TemaNord 505.

Cagossi, A. (2013). Morality Policies, Italian Style: Reluctant Secularization in a Religious World, or Un-secular Politics in a Secularizing Society? Paper presented at American Political Science Association, Chicago.

Chaqués Bonafont, L and Palau Roqué, AM (2012). From Prohibition to Permisssiveness: A Two-wave Change on Morality Issues in Spain, in I Engeli et al. (Ed.) Morality Politics in Western Europe: Parties, Agendas and Policy Choices. Basingstoke: Palgrave, pp. 62-87.

Christoph, J.B. (1962). Capital Punishment in British Politics: The British Movement to Abolish the Death Penalty 1945-57. Chicago: University of Chicago Press.

Clifford, S. \& Jerit. J. (2013). How Words Do the Work of Politics: Moral Foundations Theory and the Debate over Stem Cell Research. Journal of Politics, 75 (3), 659-671. 
Cohan. A.S. (1986). Abortion as a Marginal Issue: The Use of Peripheral Mechanisms in Britain and the United States. In J. Lovenduski and J. Outshoorn (Ed.) The New Politics of Abortion (pp. 27-48). London: Sage.

Cohen, J. \& Jones, Jr, H.W. (2004). Worldwide Legislation. In D.K. Gardner, A. Weissman, C.M. Howels and Z. Shoham (Ed.) Textbook Of Assisted Reproductive Techniques: Laboratory and Clinical Perspectives. 2nd ed. London: Taylor and Francis.

Council of Europe. (1999). The Death Penalty Abolition in Europe. Strasbourg: Council of Europe.

Cowley, P. (2001). Morality Policy Without Politics? The Case of Britain. In C.Z. Mooney (Ed.) The Public Clash of Private Values: The Politics of Morality Policy (pp. 213-226). New York: Chatham House.

Deech, R. \&. Smajdor, A. (2007) From IVF to Immortality: Controversy in the Era of Reproductive Technology. Oxford: Oxford University Press.

Donovan, T., Smith, D.L., Osborn, T. \& Mooney, C.Z. (2015). State and Local Politics: Institutions and Reform. 4nd ed. Belmont, CA: Wadsworth Cengage Learning.

Durham, M. (2005). Abortion, Gay Rights and Politics in Britain and America: A Comparison. Parliamentary Affairs, 58 (1), 89-103.

Duval, R.D. \& Groeneveld, L. (1987) Hidden Policies and Hypothesis Tests: The Implications of Type II Errors for Environmental Regulation. American Journal of Political Science, 31 (2), 423-447.

Engeli, I. (2009). The Challenges of Abortion and Assisted Reproductive Technologies Policies in Europe. Comparative European Politics, 7 (1), 56-74.

Engeli, I., Green-Pedersen, C. \& Larsen, L.T. (Ed.) (2012a). Morality Politics in Western Europe: Parties, Agendas and Policy Choices. London: Palgrave.

Engeli, I., Green-Pedersen, C. \& Larsen. L.T. (2012b). How to Study the Two Worlds of Morality Politics. In I. Engeli, C. Green-Pedersen and L.T. Larsen (Ed.) Morality Politics in Western Europe: Parties, Agendas and Policy Choices (pp. 27-34). London: Palgrave.

Engeli, I. \& Rothmayr Allison, C. (2013). Diverging against All Odds? Regulatory Paths in Embryonic Stem Cell Research across Western Europe. Journal of European Public Policy, 20 (3), 407-424. 
Engeli, I., Green-Pedersen, C. \& Larsen, L.T. (2013). The Puzzle of Permissiveness: Understanding Policy Processes Concerning Morality Issues. Journal of European Public Policy, 20 (3), 335-352.

Field, M. (1979) Determinants of Abortion Policy in Developed Nations. Policy Studies Journal, 9 (4), 771-781.

Fink, S. (2008). Politics as Usual or Bringing Religion Back In? The Influence of Parties, Institutions, Economic Interests, and Religion on Embryo Research Laws. Comparative Political Studies, 41 (6), 1631-1656. 77-96.

Fink, S. 2009. Churches as Social Veto Players. West European Politics, 32 (1),

Freeman, G. P. (1986). National Styles and Policy Sectors: Explaining Structured Variation. Journal of Public Policy, 5 (4), 467-496.

Frendreis, J. \& Tatalovich, R. (2010). A Hundred Miles of Dry': Religion and the Persistence of Prohibition in the American States. State Politics and Policy Quarterly, 10 (2), 302-319.

Gallagher, M., Laver, M., \& Mair, P. (2011). Representative Government in Modern Europe, 5th ed. New York: McGraw-Hill.

Gottweis, H. \& Prainsack, B. (2006). Emotion in Political Discourse: Contrasting Approaches to Stem Cell Governance in the USA, UK, Israel and Germany. Reproductive Medicine, 1 (6), 823-829.

Gottweis, H., Slater, B. \& Waldby, C. (2009) The Global Politics of Human Embryonic Stem Cell Science: Regenerative Medicine in Transition. Houndsmill: Palgrave Macmillan.

Green-Pedersen, C. (2007). The Conflict of Conflicts in Comparative Perspective: Euthanasia as a Political Issue in Denmark, Belgium, and the Netherlands. Comparative Politics, 39 (3), 273-291.

Grießler, E. \& Hadolt B. (2006). Policy Learning in Policy Domains with Value Conflicts: The Austrian Cases of Abortion and Assisted Reproductive Technologies. German Policy Studies, 3 (4), 698-746.

Halfmann, D. (2011) Doctors and Demonstrators: How Political Institutions Shape Abortion Law in the United States, Britain and Canada. Chicago: University of Chicago Press.

Hall, P. (1993). Policy Paradigms, Social Learning and the State. Comparative Politics, 25 (2), 275-296. 
Heichel, S., Knill, K..\& Schmitt, S. (2013) Public Policy Meets Morality: Conceptual and Theoretical Challenges in the Analysis of Morality Policy Change. Journal of European Public Policy, 20 (3), 318-334.

Hood, R. \& Hoyle, C. (2008). The Death Penalty: Worldwide Perspective. 4th ed. New York: Oxford University Press.

Hooghe, L., Marks , G. \& Schakel, A.H. (2010). The Rise of Regional Authority: A Comparative Study of 42 Democracies. London: Routledge.

Inglehart, R. \& Norris, P. (2003). Rising Tide: Gender Equality and Cultural Change Around the World. New York: Cambridge University Press.

International Planned Parenthood Federation European Network (2009). Abortion Legislation in Europe. Brussels: IPPF European Network.

Isasi, R.M. \& Knoppers, B.M. (2006) Mind the Gap: Policy Approaches to Embryonic Stem Cell and Cloning Research in 50 Countries. European Journal of Health Law, 13 (1), 9-26.

Itaborahy, L.P. \& Zhou, J. (2013) State-sponsored Homophobia: A World Survey of Laws: Criminalisation, Protection and Recognition of Same-sex Love. 8th ed. Brussels: International Gay, Lesbian, Bisexual, Trans, and Intersex Association. www.ilga.com. Accessed 25 February 2014.

Keck, M. \& Sikkink, K. (1998). Activists Beyond Borders: Advocacy Networks in International Politics. Ithaca: Cornell University Press.

Ketting, E. \& van Praag, P. (1986).“The Marginal Relevance of Legislation Relating to Induced Abortion. In J. Lovenduski and J. Outshoorn (Ed.) The New Politics of Abortion (pp. 154-169). London: Sage.

Klinh, M. \& Trappenburg, M. (eds) (2001). Regulating Physician-Negotiated Death. Gravenhage: Elsevier.

Knill, C. (2013) The Study of Morality Policy in Europe: Concepts, Theories, and Empirical Evidence. Journal of European Public Policy, 20, (3), 309-317. Macmillan.

Knill, C. \& Tosun, J. (2012). Public Policy: A New Introduction. London: Palgrave

Knill, C., Preidel, C. \& Nebel, K. (2014). Brake rather than barrier: The impact of the Catholic Church on morality policies in Western Europe. West European Politics, 37 (5), 845-866. 
Kollman, K. (2013). The Same-Sex Unions Revolution in Western Democracies: International Norms and Domestic Policy Change. Manchester: Manchester University Press.

Krabbendam, H. \& Ten Napel H-M. (eds) (2000). Regulating Morality: A Comparison of the Role of the State in Monitoring the Mores in the Netherlands and the United States. Antwerpen-Apeldoom: Maklu.

Larsen, L.T., Studlar, D.T. \&. Green-Pedersen, C. (2012). Morality Politics in the UK: Trapped Between Left and Right. In I. Engeli, C. Green-Pedersen and L. Larsen (Ed.) Morality Politics in Western Europe: Parties, Agendas and Policy Choices. (pp. 114-136). London: Palgrave.

Lijphart, A. (2012) Patterns of Democracy: Government Institutions and Performance in Thirty-Six Countries, 2nd ed. New Haven: Yale University Press.

Lowi, T. J. (1964). American Business, Public Policy, Case Studies, and Political Theory. World Politics, 16 (4), 677-715.

Marsh, D. \& Read, M. (1988). Private Members' Bills. Cambridge: Cambridge University Press.

McGann, A. \& Sandholtz, W. (2012.) Patterns of Death Penalty Abolition, 19602005: Domestic and International Factors. International Studies Quarterly, 53(2), 27589.

Minkenberg, M. (2002). Religion and Public Policy: Institutional, Cultural, and Political Impact on the Shaping of Abortion Policies in Western Democracies. Comparative Political Studies, 35 (2), 221-247.

Mintrom, M. \& Ballard, R. (2009). Governing Controversial Science: Lessons from Stem Cell Research. Policy and Society, 28 (3), 301-314.

Montpetit, E., Rothmayr, C. \& Varone, F. (2005). Institutional Vulnerability to Social Constructions: Federalism, Target Populations, and Policy Designs for Assisted Reproductive Technology in Six Democracies. Comparative Political Studies, 38 (1), 119-142.

Montpetit, E., Rothmayr, C. \& Varone, F. (Ed.) (2007). The Politics of Biotechnology in North America and Europe: Policy Networks, Institutions, and Internationalization. Lanham, MD: Lexington Books.

Mooney, C.Z. (2000). The Decline of Federalism and the Rise of Morality-Policy Conflict in the United States. Publius, 30 (1), 171-188. 
Mooney, C.Z. (Ed.) (2001). The Public Clash of Private Values: The Politics of Morality Policy. New York: Chatham House.

Mooney, C. \& Lee, M. (1999). The Temporal Diffusion of Morality Policy: The Case of Death Penalty Legislation in the American States. Policy Studies Journal, 27 (4), 766-780.

Mooney, C Z. \& Schuldt, R.G. (2008). Does Morality Policy Exist? Testing a Basic Assumption. Policy Studies Journal, 36 (2), 199-218.

Mucciaroni, G. (2011). Are Debates About 'Morality Policy' Really About Morality? Framing Opposition to Gay and Lesbian Rights. Policy Studies Journal, 39 (2), 187-216.

Neumayer, E. (2008) Death Penalty: The Political Foundations of the Global Trend Towards Abolition. Human Rights Review, 9 (2), 241-268.

Norris, P. \& Inglehart, R. (2011). Sacred and Secular: Religion and Politics Worldwide. 2nd ed. New York: Cambridge University Press.

Outshoorn, J. (1996). The Stability of Compromise: Abortion Politics in Western Europe, in M. Githens and D. McBride Stetson (Ed.), Abortion Politics: Public Policy in Cross-Cultural Perspective (pp.145-164). New York: Routledge, 1996.

Pennings, P. (2010) Exploring Morality Politics Across Space and Time: Does the 'Issue Saliency Theory' (Still) Hold? Paper presented at European Consortium for Political Research, Muenster, Germany.

Rayside, D. \& Wilcox, C. (Ed.) (2011) Faith, Politics and Sexual Diversity in Canada and the United States. Vancouver: UBC Press. Unwin.

Richards, P.G. (1970). Parliament and Conscience. London: George Allen and

Roh, J. \& Berry, F.S. (2008). Framing and Modeling the Outcomes of State Abortion Funding Referenda: Morality or Redistributive Policy, or Both? State Politics and Policy Quarterly, 8 (1), 66-87.

Rolston, B. \& Eggert, A. (eds). (1994). Abortion in the New Europe. Westport, CT: Greenwood Press.

Rothmayr, C. (2006). Explaining Restrictive ART Politics in Switzerland and Germany: Similar Processes-Similar Results? German Policy Studies, 3 (4), 595-647. 
Rothmayr, C. \& L'Espérance, A. (2010). Courts and 'Morality Policy' in Canada: Explaining Differences in Legal Mobilisation and Court Impact. Paper presented at European Consortium of Political Research, Muenster, Germany..

Rothmayr, C., Varone, F.\& Montpetit, E. (2003). Does Federalism matter for Biopolitics? Switzerland in Comparative Perspective. Swiss Political Science Review, 9 (1), 109-136.

Ryan, T.J. (2014).Reconsidering Moral Issues in Politics. Journal of Politics, 76 (2), 380-397.

Schiffino, N., Ramjoué, C. \& Varone, F. (2009). Biomedical Policies in Belgium and Italy: From Regulatory Reluctance to Policy Changes. West European Politics, 32 (4), 559-585.

Schmitt, S., Euchner, E-M. \& Preidel, C. (2013) Regulating Prostitution and Same-Sex Marriage in Italy and Spain: The Interplay of Political and Societal Veto Players in the Two Catholic Societies. Journal of European Public Policy, 20 (3), 425441.

Schwartz, M.A. \& Tatalovich,R (2009) Cultural and Institutional Factors Affecting Political Contention over Moral Issues. Comparative Sociology, 8 (1), 76-104.

Singh, S., Wulf, D., Hussain, R., Bankole, A., \&. Sedgh, G. (2009). Abortion Worldwide: A Decade of Uneven Progress. Guttmacher Institute.

Skjæveland, A. (2001). Party Cohesion in the Danish Parliament. Journal of Legislative Studies, 7 (1), 35-56.

Smith, T.A. (1969). Toward a Comparative Theory of the Policy Process. Comparative Politics, 1 (4), 498-515. Clio.

Smith, T.A. (1975) The Comparative Policy Process. Santa Barbara, CA: ABC-

Smith, T.A. \& Tatalovich, R, (2003). Cultures at War: Moral Conflicts in Western Democracies. Peterborough: Broadview Press. $\underline{2014}$.

Stem Cell World Map http://www.stemgen.org/mapworld.cfm. Accessed 1 August

Stepan, A. \& Linz, J. (2011) Comparative Perspectives on Inequality and the Quality of Democracy in the United States. Perspectives on Politics 9 (4), 841-856. 
Stetson, D.M. (Ed.) (2001). Abortion Politics, Women's Movements, and the Democratic State: A Comparative Study of State Feminism New York: Oxford University Press.

Studlar, D.T. (2001). What Constitutes Morality Policy? A Cross-National Analysis, in C. Z. Mooney (Ed.) The Public Clash of Private Values: the Politics of Morality Policy (pp. 32-51). New York: Chatham House.

Studlar, D.T. (2008) U.S. Tobacco Control: Public Health, Political Economy, or Morality Policy? Review of Policy Research, 25 (5), 393-410.

Studlar, D.T. (2012). The US and Western Europe Compared: How the 'God Gap' Led the US to Join the Religious World of Morality Politics, in I. Engeli, C. GreenPedersen and L.T. Larsen (Ed.) Morality Politics in Western Europe: Parties, Agendas and Policy Choices (pp. 161-184). London: Palgrave.

Studlar, D.T., Cagossi, A. \&. Duval, B. (2013) Is Morality Policy Different? Institutional Explanations for Post-war Western Europe. Journal of European Public Policy, 20 (3), 353-371.

Studlar, D.T. and Burn, G.J. (2014) Comparative Morality Policy Processes in Advanced Industrial Democracies: Is It Religious vs. Secular Party Systems, Europe vs. the Rest, or US Exceptionalism? Paper presented at American Political Science Association, Chicago, August 28-September 1.

Tatalovich, R. (1997). Abortion Politics in the United States and Canada. Armonk, NY: M.E. Sharpe.

Tatalovich, R. \& Daynes, B. (eds.) (2011). Moral Controversies in American Politics. 4th ed. Armonk, NY: M.E. Sharpe.

Timmermans, A. (20010. Arenas as Institutional Sites for Policymaking: Patterns and Effects in Comparative Perspective. Journal of Comparative Policy Analysis, 3 (3), 311-337.

Van Kersbergen, K. (2008). The Christian Democratic Phoenix and Modern Unsecular Politics. Party Politics, 14 (2), 259-279.

Van Koppen, P, Hessing, D.J. \& de Poot, C.J. (2002). Public Reasons for Abolition and Retention of the Death Penalty. International Criminal Justice Review, 12 (1), 77-92.

Varone, F., Rothmayr, C. \& Montpetit, E. (2006). Regulating Biomedicine in Europe And North America: A Qualitative Comparative Analysis. European Journal of Political Research, 45 (3), 317-343. 
Varone, F. \&.Schiffino, N. (2004). Regulating Red and Green Biotechnologies in Belgium: Diverging Designs of Biopolicies. Archives of Public Health, 63 (1), 83-106.

Wald, K. D., Button, J.W. \& Rienzo, B.A. (2001). Morality Politics vs. Political Economy: The Case of School-based Health Centers. Social Science Quarterly, 82 (2), 221-234.

Walsh, D.J., Ma, M.L. \& Sills, E.S. (2011). The Evolution of Health Policy Guidelines for Assisted Reproduction in the Republic of Ireland, 2004-2009. Health Research Policy and Systems, 9 (1), 28-33 
Table 1: Summary of Morality Policy Agendas: Content and Duration, by Countries

\begin{tabular}{|l|c|c|c|c|}
\hline Country & $\begin{array}{l}\text { Content } \\
\text { Total }\end{array}$ & $\begin{array}{l}\text { Mean } \\
\text { Start Yr }\end{array}$ & $\begin{array}{l}\text { Mean } \\
\text { End Yr }\end{array}$ & $\begin{array}{l}\text { Mean } \\
\text { Duration } \\
\text { Yrs. }\end{array}$ \\
\hline Australia & 7 & 1973 & 2004 & 31 \\
\hline Austria & 6 & 1975 & 1991 & 16 \\
\hline Belgium & 10 & 1987 & 2003 & 17 \\
\hline Canada & 8 & 1975 & 2003 & 29 \\
\hline Denmark & 7 & 1964 & 2002 & 39 \\
\hline Finland & 5 & 1959 & 2004 & 46 \\
\hline France & 8 & 1977 & 2010 & 34 \\
\hline Germany & 6 & 1974 & 1995 & 23 \\
\hline Greece & 5 & 1994 & 1998 & 5 \\
\hline Iceland & 7 & 1974 & 1997 & 24 \\
\hline Ireland & 5 & 1983 & 2009 & 27 \\
\hline Israel & 5 & 1974 & 1991 & 18 \\
\hline Italy & 3 & 1978 & 2003 & 26 \\
\hline Japan & 5 & 1982 & 2004 & 23 \\
\hline Luxemburg & 8 & 1984 & 2007 & 24 \\
\hline Netherlands & 9 & 1965 & 1997 & 32 \\
\hline New Zealand & 7 & 1975 & 2004 & 30 \\
\hline Norway & 7 & 1967 & 1994 & 29 \\
\hline Portugal & 7 & 1964 & 1998 & 35 \\
\hline Spain & 7 & 1980 & 2006 & 28 \\
\hline Sweden & 9 & 1961 & 1988 & 28 \\
\hline Switzerland & 8 & 1965 & 2007 & 44 \\
\hline U.K. & 9 & 1965 & 2005 & 41 \\
\hline USA & 5 & 1971 & 2013 & 43 \\
\hline Overall Mean & 6.79 & 1974 & 2001 & 28.80 \\
\hline
\end{tabular}


Table 2: Summary of Morality Policy Agendas: Content and Duration, by Individual Policies

\begin{tabular}{|c|c|c|c|c|c|c|c|c|c|c|c|c|c|c|c|c|c|c|}
\hline & \multicolumn{3}{|c|}{ Capital Punishment } & \multicolumn{3}{|c|}{ Abortion } & \multicolumn{3}{|c|}{ Euthanasia } & \multicolumn{3}{|c|}{ ART } & \multicolumn{3}{|c|}{ Same Sex Dom. Rel. } & \multicolumn{3}{|c|}{ Across All Issues } \\
\hline & $\begin{array}{l}\text { All } \\
24\end{array}$ & $\begin{array}{c}\text { Eur } \\
18\end{array}$ & $\begin{array}{c}\mathrm{N} / \mathrm{E} \\
6\end{array}$ & $\begin{array}{l}\text { All } \\
24\end{array}$ & $\begin{array}{c}\text { Eur } \\
18\end{array}$ & $\begin{array}{c}\mathrm{N} / \mathrm{E} \\
6\end{array}$ & $\begin{array}{l}\text { All } \\
24\end{array}$ & $\begin{array}{c}\text { Eur } \\
18\end{array}$ & $\begin{array}{c}\mathrm{N} / \mathrm{E} \\
6\end{array}$ & $\begin{array}{l}\text { All } \\
24\end{array}$ & $\begin{array}{c}\text { Eur } \\
18\end{array}$ & $\begin{array}{c}\mathrm{N} / \mathrm{E} \\
6\end{array}$ & $\begin{array}{c}\text { All } \\
24\end{array}$ & $\begin{array}{c}\text { Eur } \\
18\end{array}$ & $\begin{array}{c}\mathrm{N} / \mathrm{E} \\
6\end{array}$ & $\begin{array}{c}\text { All } \\
24\end{array}$ & $\begin{array}{c}\text { Eur } \\
18\end{array}$ & $\begin{array}{c}\mathrm{N} / \mathrm{E} \\
6\end{array}$ \\
\hline Mean & 1.88 & 2.00 & 1.50 & 1.58 & 1.67 & 1.33 & 0.67 & 0.67 & 0.67 & 1.29 & 1.22 & 1.50 & 1.38 & 1.44 & 1.17 & 1.36 & 1.40 & 1.23 \\
\hline Total C & 45 & 36 & 9 & 38 & 30 & e & 16 & 10 & 4 & 31 & 22 & 9 & 33 & 26 & 7 & 163 & 126 & 37 \\
\hline $\mathrm{Mec}$ & 57 & 1956 & 59 & 55 & 54 & 1959 & 1978 & 1983 & 1967 & 1981 & 1976 & 1993 & 1997 & 1996 & 1998 & 1973 & 1973 & 1975 \\
\hline Mean End Year & 1991 & 1991 & 1992 & 1995 & 1994 & 1998 & 2007 & 2006 & 2009 & 2007 & 2007 & 2007 & 2009 & 2009 & 2010 & 2002 & 2001 & 2003 \\
\hline Mean Duration & 34.92 & 35.44 & 33.33 & 40.58 & 40.72 & 40.17 & 30.19 & 24.80 & 43.67 & 27.00 & 31.67 & 15.33 & 13.50 & 13.61 & 13.17 & 29.27 & 29.32 & 29.13 \\
\hline
\end{tabular}


Table 3: Bivariate Regression Analysis of Hypotheses

\begin{tabular}{|c|l|r|r|}
\hline \multirow{2}{*}{ Hypothesis } & & Content & Duration \\
\hline \multirow{2}{*}{ Total Values } & coefficient & 0.001 & $0.958^{*}$ \\
\cline { 2 - 4 } & p-value & 0.92 & 0.01 \\
\hline \multirow{3}{*}{ Decentralization } & coefficient & -0.013 & 2.322 \\
\cline { 2 - 4 } & p-value & 0.85 & 0.13 \\
\hline \multirow{2}{*}{ Referendums } & coefficient & -0.041 & 2.242 \\
\cline { 2 - 4 } & p-value & 0.63 & 0.18 \\
\hline \multirow{3}{*}{ Party Divisions } & coefficient & 0.031 & 4.415 \\
\cline { 2 - 4 } & $p$-value & 0.51 & $0.00^{*}$ \\
\hline \multirow{3}{*}{ Legislative Initiatives } & coefficient & 0.060 & 3.840 \\
\cline { 2 - 4 } & p-value & 0.20 & $0.00^{*}$ \\
\hline \multirow{2}{*}{ Judicial Involvement } & coefficient & -0.033 & 0.181 \\
\cline { 2 - 4 } & p-value & 0.54 & 0.91 \\
\hline Constitutional & coefficient & -0.074 & 1.505 \\
\cline { 2 - 4 } Involvement & $p$-value & 0.21 & 0.38 \\
\hline
\end{tabular}


Table 4: Two Worlds: Italy as a Religious or Secular Country

\begin{tabular}{|l|r|r|}
\cline { 2 - 3 } \multicolumn{1}{l|}{ Italy Religious } & \multicolumn{1}{l|}{ Content } & \multicolumn{1}{c|}{ Duration } \\
\hline Religious $(\mathrm{N}=11)$ & 1.35 & 27.67 \\
\hline Secular $(\mathrm{N}=13)$ & 1.37 & 29.76 \\
\hline
\end{tabular}

\begin{tabular}{|l|r|r|}
\cline { 2 - 3 } \multicolumn{1}{l|}{ Italy Secular } & \multicolumn{1}{l|}{ Content } & \multicolumn{1}{l|}{ Duration } \\
\hline Religious $(\mathrm{N}=10)$ & 1.42 & 27.88 \\
\hline Secular $(\mathrm{N}=14)$ & 1.31 & 29.46 \\
\hline
\end{tabular}

Table 5: Difference of Means Test: Europe, Non-Europe, and USA

\begin{tabular}{|l|c|c|}
\cline { 2 - 3 } \multicolumn{1}{c|}{} & Content & Duration \\
\hline European $(\mathrm{N}=18)$ & 1.40 & 28.69 \\
\hline Non-European $(\mathrm{N}=5)$ & 1.28 & 26.36 \\
\hline USA $(\mathrm{N}=1)$ & 1.00 & $43.00^{*}$ \\
\hline
\end{tabular}

${ }^{*}<.01$ vs. Europe, .05 vs. non-Europe, t-tests 


\section{Endnotes}

1 In contrast, a popular U.S. textbook on state and local government (Donovan et al. 2015) has three chapters on policy, one of which is morality policy, with the others being 1 ) social welfare and health and 2 ) education. Morality policy is the longest of the three.

${ }^{2}$ From a European perspective, Heichel et al. (2013) argue that judicial involvement in policymaking is less democratic than other institutional forms.

${ }^{3}$ In the Two Worlds model, one would expect a left/right split on content of morality policy, especially in religious party systems. While this hypothesis will be tested here, the Roman Catholic Church changed its attitude toward the death penalty to support abolition after Vatican II in the early 1960s although it never made this position as central to its political arguments than the other morality issues have been. Furthermore, there is a long tradition of members of left-wing parties being prominent advocates in debates on this issue (van Koppen et al. 2002; McGann and Sandholtz 2012) as well as on others.

${ }^{4}$ There is a third perspective on morality policy, that it depends on framing of the issues, but this may vary across groups, individuals, and jurisdictions (Knill 2013). For applications of this approach in the US, see Wald et al. (2001), Roh and Berry (2008), Mucciaroni (2011). Engeli et al. (2012a) use party manifestos to address framing in some European countries. Since we have no indicators of framing in our larger universe of countries, we cannot address this perspective.

${ }^{5}$ As Baumgartner and Jones (1993) emphasize in punctuated equilibrium (PET) theory, multiple venues in the US can provide opportunities as well as constraints for policy change, a two-edged sword. Thus they are not 'veto points', strictly speaking, in that all venues may not have to agree via explicit decision to each policy. On veto points, see Stepan and Linz (2011).

6 In effect, a cumulative total of institutions employed in morality policy constitutes an unweighted institutional index. No version of Policy Type theory weighs the importance of different institutions. In addition, since available institutions vary by country, weighing them would be difficult to do.

${ }^{7}$ One reviewer contended that parties are not a venue, but an actor within an institutional framework. That is how the Two Worlds explanation treats parties, but the Policy Type explanation argues that party division is a an institutional characteristic for morality issues. Thus we offer a traditional hypothesis based on that model. See Smith (19750,; Smith and Tatalovich (2003), Tatalovich and Daynes (2011).

${ }^{8}$ The death penalty has uniformly been abolished by all 18 West European democracies. In the broader realm of 24 Western democracies, an "intermediate" score 
is obtained in the U.S., Israel, and Japan since it is used in highly restricted circumstances.

${ }^{9}$ The Christian Democratic International became the Centrist Democrat International in 2001, thus confusing the formal distinction between Christian Democratic and other conservative parties. Similarly, the European People's Party in the European Parliament contains a broad array of center-right parties. Italy can be considered to have at least two confessionally-oriented parties (with former Christian Democratic members) similar to Spain. In the latter country, the Popular Party is highly religiously-influenced through church organizations and positions taken on morality issues rather than explicit connections between churches and parties (Chaqués Bonafont, and Palau Roqué 2012). The recent attempt to restrict abortion laws is an example of this. On the other hand, France and Greece also have parties in the Centrist Democrat International, but they do not have such religious ties. Ireland also has one party (Fine Gael) in the Centrist Democrat International.

10 Since the data are not coded on policy actions by individual years, we cannot perform any type of time-series or event history analysis. Thus we cannot examine the effects of the 1970s regime changes from democratic to authoritarian and then back to democratic in Greece, Spain, and Portugal. We also do not make fine distinctions on institutions across countries, for instance, between those where use of the referendum is restricted to constitutional issues (Denmark) and those where it is more widely permitted (Switzerland). These questions are left for others to examine although we do address the stability of results for the three countries without a continuous post-1945 democratic history in endnote 12.

${ }^{11}$ In examining the nature of the relationship between the variables and determining whether there is sufficient ground to state that an increase in one variable results in a consistent change in another, we conducted a bivariate linear regression analysis. A difference of means test was used to determine whether there is a statistically significant difference between identified groups. In determining differences between two groups (European vs. Non-European; European vs. USA; Non-European vs. USA), a ttest was used where an assumption of similar variances was made. Where there are three groups being compared together and against each other (European vs. NonEuropean vs. USA) a simple ANOVA test was used. The non-parametric Mann-Whitney (rank sum) test was used to examine the relationship between the approaches to morality policy within the target countries. The Mann-Whitney $U$ typically provides comparable power to the standard two-sample t-test when the assumptions of the t-test are met, and is somewhat more robust when the assumptions are violated (e.g., normality). For an extended examination of the relative power of the two approaches, see Duval and Groeneveld (1987). Thus the results for the Mann-Whitney U test in Table 4 are very similar, although overall somewhat stronger, than conventional difference of means t-tests of the same data (not shown). Since the overall mean and median are close in value, with the exception of total venues (expected, since some 
countries have more available venues than others), the distribution of scores is relatively symmetrical.

${ }^{12}$ In this study we do not consider the dates of legalization of homosexuality, which of course affects the same sex domestic relations debate but occurred decades, and some cases centuries, before the more specific debate about legalizing ongoing same-sex relationships.

${ }^{13}$ Since three countries (Greece, Portugal, and Spain) have had interrupted democratic histories post-1945, we compared the results for these three countries with those of the other 21. There were no meaningful changes in the results from those of the original analysis for all 24 countries. The most significant difference occurred for the first hypothesis (more venues lead to less permissive regimes), which shifted from a slightly positive coefficient to a slightly negative one. A high p-value, however, indicates that these results are not reliable. Contact the authors for a copy of this analysis.

${ }^{14}$ Some commentators have questioned whether capital punishment has enough similarities with other morality issues. Thus, tables 3-5 were recalculated excluding the death penalty. The results were very similar to those presented here, with four significant results for data in Table 3. Three were the same as previously, with significant results on duration for total venues, party divisions, and legislative initiatives. In the fourth, decentralization is significant on duration. In the recalculated Table 4 there were no significant differences between religious and secular party systems. With Italy as secular, the groups are not significantly different on anything. The recalculated Table 5 indicates that the U.S. is significantly different from other non-European countries on duration $(0.05$ level), with the U.S. earlier and longer, but there are no significant differences from European countries. While there are some differences, analysis of other individual issues would also find differences, and our overall conclusion is that the death penalty has more similarities than differences with other morality issues, despite its seemingly definitive resolution in more countries than the other policies. Contact the authors for a copy of this analysis. The issue of how each individual issue fares across these 24 countries is worthy of a separate paper, currently in preparation.

${ }^{15}$ Candidates include race and ethnic relations, women's rights, drugs, gambling, prostitution, guns, alcohol, tobacco, obesity, religious practices, animal rights, and immigration. See Studlar (2001; 2008), Tatalovich and Daynes (2011), Knill (2013).

${ }^{16}$ Two such possibilities are the refinement of the three-point ratings system to include finder gradations, as well as an index of the role of religion and party competition, especially one that would be sensitive to developments over time since all of the dependent variables except current policy are time-dependent. 